\section{Tapping into the Appeal of Cult Fiction}

\section{Kelly Fann, Guest Columnist}

Correspondence concerning this column should be addressed to Barry Trott, Adult Services Director, Williamsburg Regional Library, 7770 Croaker Rd., Williamsburg, VA 23188; e-mail: btrott@wrl.org.

Kelly Fann is the Director of the Tonganoxie (Kans.) Public Library.
Readers' advisors are well aware of the growing trend in publishing toward cross-genre writing. Whether it is a mystery with a vampire detective, a futuristic romance, or inspirational thriller, readers are enjoying books that defy standard genre classification. As Kelly Fann discusses in her article, cult fiction is a classic genre bender, though one that is frequently overlooked by readers' advisors. Here, Fann explores what makes a title a cult favorite, how readers respond to these titles, and what librarians can do to better serve the reading interests of this part of their reading community. Kelly Fann is director of the Tonganoxie (Kans.) Public Library and adjunct faculty for Emporia State University in Emporia, Kansas. She is a regular RA presenter across Kansas and Missouri and reviews books for MonsterLibrarian.com._Editor

$\mathbf{T}$ he tattered paperback book sat crammed between two now-forgotten titles on my grandmother's bookshelf for several years before I picked it up in a fit of boredom. It probably hadn't been looked at or even fingered in five times as many years as I passed it over. The pages were yellowed and they smelled something terrible, but I read it anyway, and I read it in one sitting. I can tell you how old I was, the season, what the weather outside was like, what time I started the book, when I finished it, how often I got yelled at and told to get out of that chair and do something constructive, and how I would not shut up about it for many weeks thereafter. Brave New World by Aldous Huxley was my first foray into cult fiction and it will forever be emblazoned as my "life changing" text of choice. This is what cult fiction books do to their faithful followers: they inspire, amuse, and amaze their readers, they stir the emotions and mesmerize, they evoke passion, and they etch themselves into their reader's memory. It is for these reasons and many more that cult fiction titles are a powerful resource for librarians to tap into when helping their patrons find their next greatest read.

\section{CULT FICTION AND ITS APPEAL}

Before we begin, it is important not to confuse cult fiction with the horror genre's "occult," or with fiction written about the idea of a "cult" from a religious or sociological definition. Cult fiction more closely aligns with the concept of "cult classic" in that it has achieved rogue literary phenomenon status; however, defining what constitutes cult fiction can be a daunting task, as there are many determining factors. For 
an added bit of complexity, not all of these parameters must be met to achieve cult fiction status.

Cult fiction tends to be groundbreaking literature, either through its prose style or through the subject matter the author has chosen to discuss. Subjects often cover lurid topics such as sex and drugs, or will include criticism of the establishment through exploration of the human condition or creation of dystopian societies. Many cult fiction titles incorporate spur-of-the-moment adventurous travel, as it is the path traversed that aids in scrutiny of the subject matter. At the time of their publication, titles destined to join the cult fiction canon burst onto the scene, are quickly deemed as being filled with explicit or controversial content, and thus garner greater attention. The icons of the cult fiction canon, Brave New World, Catcher in the Rye, Do Androids Dream of Electric Sheep? along with others, often were banned or contested quickly after publication, intensifying their seduction. Once a title finds its way to the banned bookshelf, reader intrigue skyrockets as readers seek to discover and experience the book's mystique for themselves.

In my opinion, Jane Sullivan posits the most concise definition of cult fiction: "whatever it is, cult fiction makes the heart beat faster . . . it speaks to you in a way nothing else does, and you're convinced you're the only person who gets it." As more and more readers react to a book in this same manner, feeling as though they are the only people who understand what the author really means, the cult status of the title begins to develop. Sullivan accurately identifies why titles achieve cult fiction status: they speak to the reader in a way that no other book has done before, almost as if the author wrote the book in question specifically for the reader. According to Thomas Reed Whissen, cult fiction appeals to readers who feel "cut off, socially disenfranchised, deprived of their rightful place in the community of man."' He explains that these disenfranchised individuals as a group make up the cult following of the title; however, as cult membership is through the book, no interaction is required of them. They merely feel part of the greater whole: the cult.

Whissen identifies several key literary elements of cult fiction canon members. Of these, alienation, ego-reinforcement, behavior modification, and vulnerability interact with one another to make cult fiction strikingly appealing to adults in their 20s and 30s as well as to teen readers.

\section{Alienation}

The main character in cult fiction books is quite often seen as alienated from the world around him/her. Take Sal Paradise in Jack Kerouac's On the Road. While Sal may have interactions with his small group of friends, the story on the whole revolves around his cross-country adventures. Particularly on how his completely uninspired outlook on life seems to differ so drastically from the world around him, leaving him unable to connect with it. Breakfast of Champions, Lord of the Flies, Catcher in the Rye, and 2001: A Space
Odyssey are just a few of the numerous cult fiction titles featuring the alienated hero.

\section{Ego-Reinforcement}

According to Whissen, cult fiction books must first and foremost "stroke the egos" of their readers. The reader identifies with the alienated hero, and "rejoices" in what he/she sees. As the hero finds him/herself rejected by society, the reader similarly feels this rejection, thus forging the connection between book and reader.

\section{Behavior Modification}

Once a reader identifies with the alienated hero and the connection between book and reader has been forged, a change in the reader's outlook on life will begin to take place. This is where a change in world view comes in. Cult fiction titles offer an opportunity for readers to experience a pivotal moment of clarity to see the world beyond the stereotypical or mainstream consciousness. Any cult fiction title has the potential to bring about this effect.

\section{Vulnerability}

Through alienation, ego-reinforcement, and behavior modification all play very important roles in establishing cult fiction status, one pivotal piece often brings about the strongest response to the title: vulnerability. Whissen identifies the element of vulnerability as a situation in which the reader blindly accepts what he/she "believes the book is saying." This is your "reading this book changed my life" response. These readers are the most die-hard of fans who will ardently debate the title's contents and what they believe the author was trying to say. The more readers that feel this way, the more powerful the cult status.

Quite simply put, a title achieves cult fiction status purely based on its reception by readers. This is what sets the cult fiction genre apart from the standard genres of romance, fantasy, science fiction, and so on. Authors knowingly write books that fit into these genres; they do not, however, knowingly write a cult fiction book. The reader response to a title creates cult fiction status. When a book speaks not only to the reader, but for the reader, cult fiction status is in the making. Cult status is achieved when the title is widely read and numerous readers feel the book speaks to them and for them.

While the cult fiction canon is filled with gut-wrenching, stomach-turning, pulse-skyrocketing titles, it is simultaneously filled with heart-breaking and emotionally charged memoirs, feminist literary theory texts crucial to modern feminism, and ground-breaking and often imitated styles of fiction.

Cult fiction stands the test of time as titles continue to be reprinted (and contested). ${ }^{3}$ Walk into any library, and 
you are likely to find A Tree Grows in Brooklyn, Catch-22, Slaughterhouse-Five, and numerous other cult fiction titles on the shelf. Cult fiction titles are also readily available in audiobook and e-book format, and many have been made into movies. Although cult fiction stands on its own as a reading interest, cult fiction titles will fall into other genres. Warlock by Oakley Hall will be found in westerns, Interview with a Vampire by Anne Rice will be found in horror, and Neuromancer by William Gibson will be found in science fiction. Many cult fiction titles will likely be shelved with general fiction.

\section{GENRE PLURALITY = POTENTIAL FOR GENRE EXPLORATION}

While you may initially think you don't know many cult fiction titles, on reflection you will find you know far more than you realize. Pretty much all cult fiction titles can be identified as belonging to another genre or subgenre. Isaac Asimov titles are identified as being part of the cult fiction canon, but I'm willing to bet that nearly all libraries have these titles shelved with science fiction, as they should be. I highly doubt many, if any, libraries actually have a section devoted to cult fiction, and I don't necessarily recommend creating one either. Here are the two main reasons: (1) readers who are not aware of what cult fiction encompasses could very easily be turned off merely by the word "cult," and (2) your devoted science fiction, fantasy, non-fiction, or any other genre readers expect to find these titles shelved in their respective sections. If they go to those shelves and don't find the titles they expect to see, they won't immediately think to check the cult fiction section. What this means is that it is up to librarians to familiarize themselves with cult fiction titles, or at a minimum, cult fiction resources. ${ }^{4}$ By gaining this knowledge, you will be better prepared to begin suggesting titles for readers who are looking for something different from their usual reads.

As cult fiction titles straddle multiple genres, they serve as a perfect bridge for genre exploration. If you have someone who finds science-fiction too full of hardcore science and not enough action, look no further than Snow Crash by Neal Stephenson. If Horror is too cheesy or scary, turn to The Stand by Stephen King. In some ways, the label "cult fiction" is a misnomer, or at least, the inclusion of "fiction" causes it to be a misnomer, as the cult fiction canon holds many non-fiction titles. For the fiction reader who finds non-fiction boring or too slow in pace, suggest a cult fiction title to help them explore a grittier, sometimes seedier side to non-fiction. Another Bullshit Night in Suck City by Nick Flynn, Running with Scissors by Augusten Burroughs, and The Beauty Myth by Naomi Wolf aren't your standard nonfiction fare. Or what about someone looking for something different from their standard reads? They want something that will change their world view, get them out of their reading rut. Cult fiction is the direction you should turn. These titles entered into cult fiction status precisely because they changed the world view for so many readers.

\section{CULT FICTION SUGGESTIONS FOR GENRE EXPLORATION}

\section{Dystopia}

- 1984 by George Orwell

- Fahrenheit 451 by Ray Bradbury

- Battle Royale by Koushon Takami

\section{Fantasy}

- The Once and Future King by T. H. White

- The Hitchhiker's Guide to the Galaxy by Douglas Adams (this could arguably go under science fiction; however, hardcore science-fiction fans will be remiss to see it labeled as such.)

- The Belgariad series by David Eddings

\section{Horror or Thriller}

- Interview with the Vampire by Anne Rice

- The Killer Inside Me by Jim Thompson

- American Psycho by Bret Easton Ellis

\section{Nonfiction}

- Zen and the Art of Motorcycle Maintenance: An Inquiry into Values by Robert M. Pirsig

- Oranges are Not the Only Fruit by Jeanette Winterson

- Let that be the Reason by Vickie Stringer

- No Logo by Naomi Klein

\section{Science Fiction}

- Dune by Frank Herbert

- Neuromancer by William Gibson

- Snow Crash by Neal Stephenson

\section{Subculture}

- Fight Club by Chuck Palahniuk

- Trainspotting by Irvine Welsh

- A Clockwork Orange by Anthony Burgess

\section{EASING TEENS INTO ADULT LITERATURE}

It's a scenario we all hope to find ourselves in: a teen reader is ready to branch out beyond the YA section and into adult fiction, but he has no idea where to start. He's looking for something gritty, edgy and that won't turn him completely off from adult titles. Pick a standing member of the cult fiction canon and you're likely to pick a winner and win over a new 


\section{READERS' ADVISORY}

follower of the genre.

A study into the trends of Printz Award winning books shows all the characteristics of cult fiction readers in the making. The study revealed six common trends including "journeys, teenage angst leading to self-actualization, family relationships, romantic relationships, controversial issues within the content, and diversity of story characters." Of those six, the first five elements are key elements in achieving cult fiction status. If the young adult titles winning awards showcase these elements, then it is safe to say these same teen readers will welcome cult fiction titles with open arms.

William Sutcliff takes this a step further when he quite bluntly states that cult fiction titles are "important to read as [teens] enter adulthood." He explains that cult fiction titles provide the perfect opportunity for teens to safely explore everything that could be done in life: "[a]t 18, anything is possible, and you have to read these books to find out what 'anything' really means." ${ }^{\prime \prime}$ In his view, cult fiction titles serve as a right of passage into adulthood.

As noted earlier, the subject matter of cult fiction tends to have two common elements: it will be both explicit and controversial. Explicit and controversial attract teen readers. Look at the currently hot YA titles; many are hard hitting discussing the difficult subjects faced by teenagers today. These same titles often find themselves on the American Library Association's Banned Book List, heightening their esteem for teen readers. ${ }^{7}$ When adult counterparts deem a title too explicit, too edgy, teens gravitate to the book, if only because the self appointed authorities have said they shouldn't read it. As current cult fiction titles were frequently banned or contested at their time of publication, it stands to reason that the banned books of today will reach cult fiction status in the future.

How many cult classic fiction books our youth and our parents' youth have become high school or even junior high school required reading? My father talks about how pivotal reading Lord of the Flies was for him, and it was part of my freshman English curriculum. Animal Farm, Farhenheit 451, and 1984 all fall into this same category for me. Obviously these titles were initially written with adult readers in mind; however, they have already bridged the gap into teen literature. This trend will likely continue. I can easily see Fight Club by Chuck Palahniuk and Trainspotting by Irvine Welsh moving beyond merely cult fiction status and making the list of required reading in the near future.

Cult fiction crosses from juvenile fiction into young adult literature and into adult fiction, thus making it a perfect bridge. Robert Cormier's The Chocolate War was written as adult literature, yet you will find it on young adult and juvenile shelves. S. E. Hinton's The Outsiders is often seen as laying the groundwork for young adult literature-and it very much belongs in the cult fiction canon. With cult fiction, time allows the lines to blur between intended audiences. Your teen readers may already be reading cult fiction titles, just not the ones you have shelved in the adult section.

\section{CULT FICTION SUGGESTIONS FOR TEEN READERS}

- The Bell Jar by Sylvia Plath

- Crash by J.G. Ballard

- The Dice Man by Luke Rhinehart

- Dune by Frank Herbert

- Fight Club by Chuck Palahniuk

- The Hitchhiker's Guide to the Galaxy by Douglas Adams

- Geek Love by Katherine Dunn

- Magic for Beginners by Kelly Link

- Neuromancer by William Gibson

- One Day in the Life of Ivan Denisovich by Alexander Solzhenitsyn

- One Flew Over the Cuckoo's Nest by Ken Kesey

- Only Forward by Michael Marshall Smith

- One Hundred Years of Solitude by Gabriel Garcia Marquez

- Perfume by Patrick Süskind

- The Pigman by Paul Zindel

- The Stranger by Albert Camus

- Trainspotting by Irvine Welsh

There is something about cult fiction titles that make them easily spotted. You may have started reading this article completely unaware of cult fiction, but I'm willing to bet that you're already adding additional titles to the ones I've listed. Once you know the genre, you instinctively know which titles belong in it.

\section{References}

1. Jane Sullivan, "Cult Call a Rough Guess at Best," The Age, June 2, 2007, Entertainment section, www.theage.com.au/news/books/ cult-call-a-rough-guess-at-best/2007/05/30/1 180205324054 .html (accessed Feb. 28, 2011).

2. Thomas R. Whissen, Classic Cult Fiction: A Companion to Popular Cult Literature (New York: Greenwod, 1992): x-xxxvii.

3. American Library Association, "Banned and/or Challenged Books from the Radcliffe Publishing Course Top 100 Novels of the 20th Century," www.ala.org/ala/issuesadvocacy/banned/frequentlychallenged/challengedclassics/reasonsbanned/index.cfm (accessed Jan. 20, 2011).

4. Paul Simpson, Michaela Bushell, and Helen Roddis, The Rough Guide to Cult Fiction (London: Rough Guide, 2005); Andrew Calcutt and Richard Shephard, Cult Fiction: A Reader's Guide (Lincolnwood, Ill: Contemporary Books, 1999)

5. Joni Richards Bodart, Ashley N. Barrineau, and Mary L. Flamino, "The Printz Award Winners Under a Microscope: Content Trends, Committee Challenges, and Teen Popularity," Journal of Research on Libraries \& Young Adults 1, no. 2 (Feb. 2011), www.yalsa .ala.org/jrlya/2011/02/the-printz-award-winners-under-a-micro scope-content-trends-committee-challenges-and-teen-popularity (accessed Feb. 28, 2011).

6. William Sutcliffe, "Cult Books," in The Ultimate Teen Book Guide, ed. Daniel Hahn, Leonie Flynn, and Susan Reuben (New York: Walker, 2008): 250-51.

7. American Library Association, "Frequently Challenged Books of the 21st Century," www.ala.org/ala/issuesadvocacy/banned/frequ entlychallenged/21stcenturychallenged/index.cfm (accessed Jan. 18, 2011). 